\title{
Mountain of Transfiguration \& New Discoveries in Site of Jesus Baptism / Jordan River
}

\author{
Mohammed Waheeb \\ Queen Rania College of Heritage \& Tourism \\ Hashemite University \\ Amman- Jordan \\ E-mail: mwaheeb@hu.edu.jo
}

\begin{abstract}
The amazing account of the Transfiguration of Christ on a mountain; is a dramatic event marks a major turning point in the Gospel Narratives, for Jesus was beginning to turn more and more to Jerusalem and the suffering and last days that awaited Him by God there. But before all of that would take place, there was this glimpse of glory. This article discuss in details the new evidences for the proposed or even the real place of the Transfiguration according to recent Roman \& Byzantine archaeological discoveries in Bethany Beyond the Jordan on the eastern bank of Jordan River . The discoveries include monasteries, churches, water installations, caves \& footpaths located \& found during systematic survey and excavations during 1997upward on eastern side of Jordan River.
\end{abstract}

Keywords: Archaeology, Religions, Excavation, Roman, Byzantine. Heritage.

\section{Introduction:}

The word "Transfiguration" comes from the Latin roots Trans- ("across") and figure ("form, shape"). It thus signifies a change of form or appearance. This is what happened to Jesus according to the gospels in the event known as the Transfiguration, His appearance changed and became glorious.

Before looking at the Transfiguration itself, it's important that we look at what happened immediately before it in Luke's Gospel. ${ }^{1}$ The Transfiguration (Luke 17:1-3).the central point of the first three verses focuses on one word-and indeed, this word is the center of the whole passage. "Transfigured" The Greek term is well-known in English; from metamorphous (pronounced meta-mor-phaw-o) we get our word "metamorphosis."(International Encyclopedia: 1915) First, we have the record of the event of the Transfiguration (verses 1-3) which happened during 29AD approximately. Second, Peter's suggestion and the divine response to it (verses 4-8). And third, the instruction by Jesus and the question by the disciples (verses $9-13)^{2}$

\section{Methodology:}

All previous studies were subjected to deep analysis in order to build these new evidences on strong foundation supported by absolute chronology gained through survey, systematic excavations in Bethany Beyond the Jordan, analysis of the gained data, and comparative study.

Before our recent excavations in Bethany Beyond the Jordan during 1996 It is impossible to decide positively which was the Mount of Transfiguration. And it is not a matter of much consequence. Those who think it was Hermon are at liberty to think so; and those who think it was Tabor, have a right to their opinion, for none can prove that they are mistaken in thinking so.

\section{The Traditional Locations (fig:1)}

It may be a small point, but it is worth noting that there are two traditions about the location of the Mount of Transfiguration. First:

\footnotetext{
${ }^{1}$.In fact, Luke notes that the Transfiguration took place "about eight days after these sayings," thus stressing its proximity to them and suggesting that it was the fulfillment of this saying, concerning the fact that some of them would see the kingdom of God. Mark gives a different number of days, saying it was "after six days" (Mk. 9:2), but these both approximate a week.( 3)for more details see( Matt 13: 1617) ( Matt 16: 26-27)

${ }^{2}$ The fact that Jesus only allowed three of his disciples to witness the event may have sparked the discussion which swiftly ensued about which of the disciples was the greatest (Luke 9:46). The three who are privileged to witness the event are Peter, James, and John, the three core disciples.
} 
The Roman Catholic tradition identifies it as Mount Tabor, south of the region of Galilee, on the northern edge of the Jezreel Valley. As one would expect, there are chapels and churches on the top of the Mount built to commemorate the spot.

Second: The other view; is that Mount Hermon is the site of the Transfiguration, located in the far north, of where Caesarea Philippi is situated. Generally but not specifically it would make sense for the Transfiguration to take place in that region down along the route of Jordan River to the Dead sea area, where Jesus had been ministering and where Peter made his confession. Of course, there is a week's time for them to get almost anywhere.

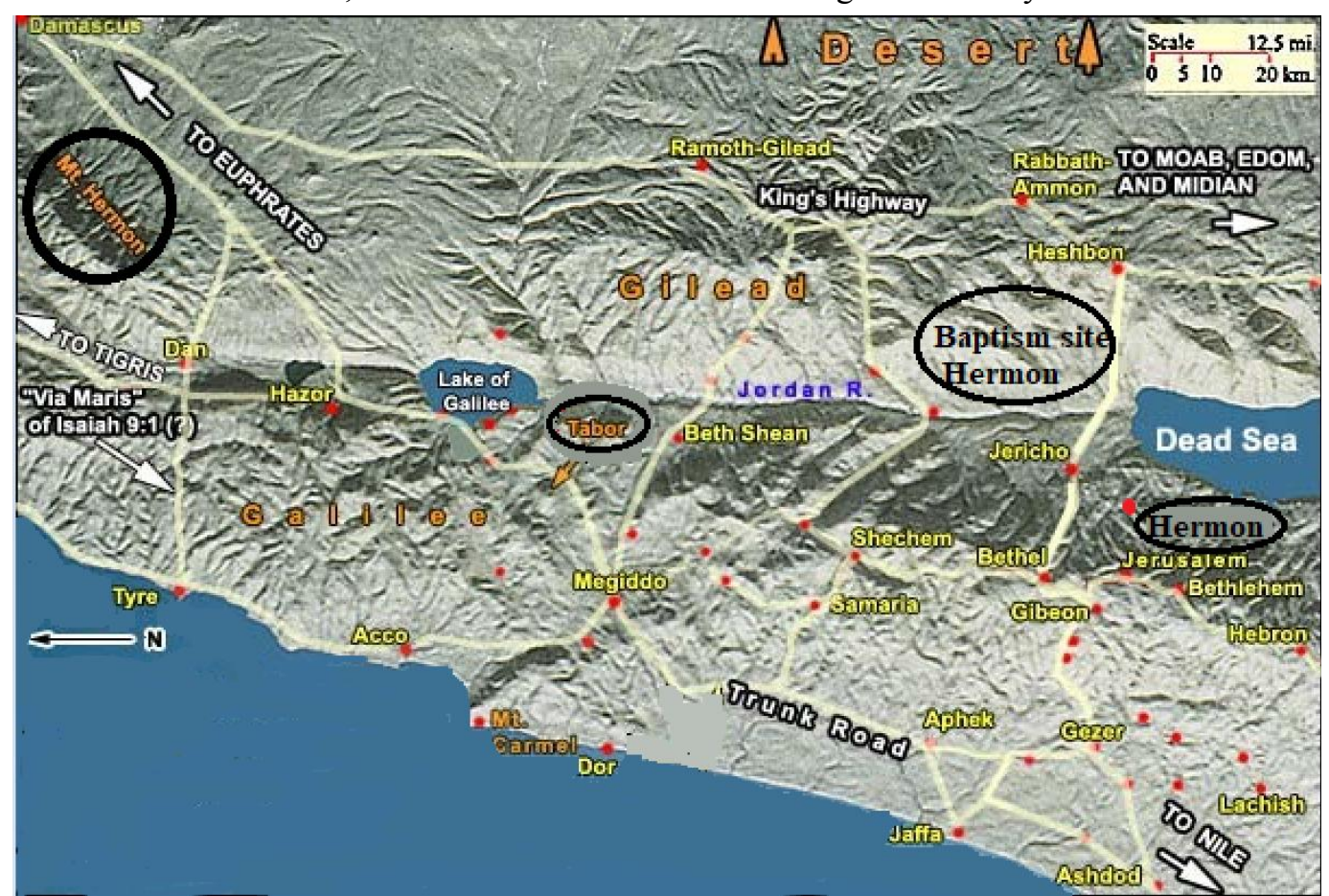

Fig 1: A map showing the different locations of Hermon Mountains in the holy land

The main question arise here is where is the real Mountain of Transfiguration?

Jesus appeared on a mountain to three of his disciples in the mysterious event known as the Transfiguration; where this event happened?

We have no indications for this event even the mountain of the Transfiguration is wrapped in mystery. The critical point is that they went up to the place away from all the people; its isolation gives it majesty. Using mountain tops for spiritual experiences and for shrines; was common throughout the ancient world and since the instinct of coming up out of the world was a good one, God also used it to reveal himself, for example Mount Sinai, the sermon on the mount, the mount of the Transfiguration, and Mount Hermon.

Here some details regarding the traditional proposed sites for Transfiguration in the holy land:

The first site Mount Tabor is dome-shaped located 9KM east of Nazareth, at the north-east corner of the (Jezreel) Valley. It is a round steep hill (613M above sea level, and 460M above the valley), visible from the whole area. It is not an extinct volcano, although it does look like one. It played an important role in the biblical history, and tradition links it to the Transfiguration of Jesus. Mount Tabor is not a very large mountain, and it was inhabited at the time. The local inhabitants still call it by its Aramaic name Et-Tor .

It had a prime location in the ancient times, and there were several roads that crossed it, Via Maris lower to upper Galilee, Jordan valley (via Tabor creek), and Decapolis (Scythopolis) via EinDor. The hill is strategically was an important fortress during the Late Iron Age, Greek, Roman and Crusaders times,

From the hill there is a magnificent view of Jezreel valley, the hills around it including, and to the North - Mount Hermon.

The second site, Hermon. Derived from Hram means sacred sanctuary set apart for a designated holy purpose. The root-verb (haram) is thought to be cognate with an Arabic verb that means to be prohibited or become sacred. It is one of the most conspicuous mountains, a peak, the eastern prolongation of the Anti-Lebanon Range. . 
Mt Hermon covered by snow most of the year the snow -capped peak of Hermon was like a finger pointing heavenwards, but without any significant attraction for human settlement through Ages . According to literature \& geographical studies there are tow Hermons, one is a peak on the high mountain range in southern Lebanon, just north of the Sea of Galilee.

The other is an area in a valley below the summit of Mount Tabor just six miles east of Nazareth. This second site was once known as Little Hermon. ${ }^{3}$

Hermon summit straddles the border between Syria and Lebanon and at 2,814 m (9,232 ft) above sea level, is the highest point in Syria., The (Anti-Lebanon Range), of which the Hermon range constitutes the southernmost part, It can be seen from as far away as the Dead Sea-120 miles. The range is approximately 28 miles in length and reaches a width of 15 miles. Its peak is also covered with snow two-thirds of the year. Water from its melting snow flows into the rivers of the Hauran and provides the principal source for the Jordan River, running parallel to the Lebanon range on the west. The Hermon range covers an area of about $700 \mathrm{~km}^{2}(270 \mathrm{sq} \mathrm{mi})$ of which about $70 \mathrm{~km}^{2}(27 \mathrm{sq} \mathrm{mi})$ are under Israeli control. Most of the portion of Mount Hermon within the Israeli-controlled area constitutes the Hermon nature reserve. The entire relatively narrow range, with the Lebanon-Syria boundary along its spine, extends from $25 \mathrm{~km}$ northeast of Mt. Hermon to $45 \mathrm{~km}$ southwest of it.

Mt Hermon is distinguished \& significant for three reasons as follow:

(1) It was representing the northern border of the Amorite kingdom (Deuteronomy 3:8 ; 4:48, also see Joshua 13:5 ), (2) Always has been regarded as religious or sacred mountain. ${ }^{(3)}$ Some scholars believe that Jesus was transfigured here. Its modern name is Jebel-ash-Sheikh, "the chief mountain."

\section{Description of Historians \& Travelers}

More information's and details could be followed from literature studies description of pilgrim's travelers and history experts :

\section{A- Mount Tabor}

The Mount of the Transfiguration had become the "Holy Mount" (2 Peter 1:18). It seems to have been known by the faithful of the country, and few traditions identified it with Mount Tabor. This mountain is often thought generally to be Mt Tabor in the north, but none of the gospels identify it precisely.

Some previous \& modern studies as well as scholars claim that the Transfiguration could not have taken place on Mount Tabor Origen said (A.D. 231-54): "Tabor is the mountain of Galilee on which Christ was transfigured" (Comm. in Ps. lxxxviii, 13). Origen is the only and first who mention that the Transfiguration occurred on Tabor ( for more details see ( PG Migne :Patrologia Graeca ,12,1548), While Abel cast doubt on Origen opinion and its authenticity (Abel 1938,355) Eusebius of the fourth century was unaware and not sure of this location and added ( I think that the wonders Transfiguration of our Redeemer took place on three mountains, and that he often stayed on them during the period of his life with men ). When he mentioned Tabor he says nothing about Transfiguration(Eusebius :1904, 98).The appearance of Jesus to the eleven on a mountain in Galilee (Matt: 28, 16-20) made confusion to Eusebius to decide on which mountain was the scene of the Transfiguration.

\footnotetext{
3 . "According to International Standard Bible Encyclopedia". 1915 Little Hermon, the name now often applied to the hill between Tabor and Gilboa, possibly the Hill of Moreh, on which is the sanctuary of Neby Dahy, has no Biblical authority, and dates only from the Middle Ages.
} 


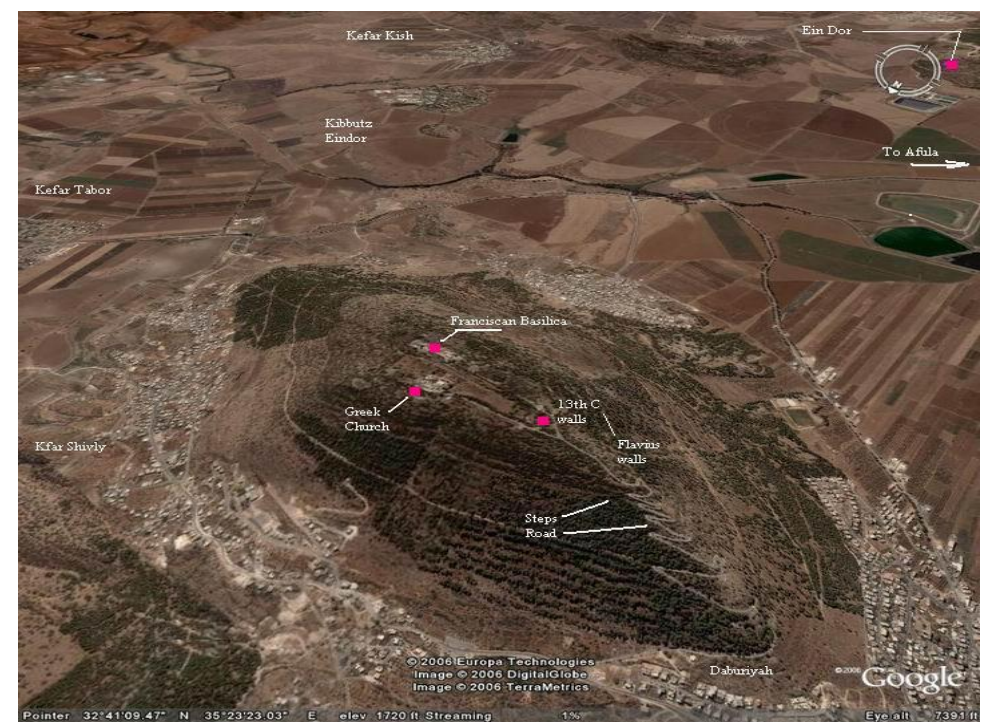

Fig: 2 General view of Tabor mountain as proposed for Transfiguration

Josephus ,Eusebius , and Jermo refers to Tabor as Atabyrion which is the ancient Asia Minor name/ word for mountain ( Boehmer : 1929,163 see also, Alt :1934,26).Josephus gives more explanations about Tabor during 66AD where fortifications built on mount Atabyrion, which means that the mountain was continuously inhabited since 2018BC . Antiochus the Great wrested Tabor after defeating the Ptolemies during $218 \mathrm{BC}$ and built a garassion on the top (Leipzig: 1889,191) accordingly this not rule it out as the site of Transfiguration. (Meistreman: 1900, 76).

Modern studies and scholars claim that the Transfiguration could not have taken place on Mount Tabor, The town of Atabyrion of Polybius, the Tabor or Celeste Tabor, the "flank of Tabor" of the Bible, is situated at the foot of Mount Tabor.

The Gospel according to Hebrews dated to 150AD makes Jesus say :

" Straightway my mother, the Holy Spirit, took hold of me and carried me up to the great mount Tabor )" but again this Gospel is not from the officially adopted four Gospels to rely on and to build strong foundation on it , and not help in locating precisely the Transfiguration Hill see (Abel : 1938,354)

In the fourth century St. Cyril of Jerusalem and St. Jerome likewise followed Origen ${ }^{4}$ who depended on Gospel according to Hebrews and copied and declare it categorically without any investigation or field searching . Later St. Proculus, Patriarch of Constantinople (d. 447; Orat. viii, in Transfiguration.), and Agathangelus (Hist. of Armenia, II, xvii), and Arnobius the Younger (d. 460; Comm. in Ps. lxxxviii, 13) say the same thing.

The testimonies increase from century to century without a single dissentient note, and in 553AD the Fifth Council of Constantinople erected a see at Mount Tabor (Antiochian Patriarchate).

By 570, three Byzantine churches are recorded as standing on Mt. Tabor, one large church with chapels dedicated to Christ, Moses and Elijah.

In 1808, Henry Alford cast doubt on Tabor due to the possible continuing Roman utilization of a fortress which Antiochus the Great built on Tabor in BC219, and which Josephus records was in use by the Romans in the Jewish War. Others have countered that even if Tabor was fortified by Antiochus this does not rule out a Transfiguration at the summit.

\footnotetext{
4 . Origen: (c. 184 - c. 253), also known as Origen Adamantius, was an early Christian scholar, ascetic, and theologian who was born and spent the first half of his career in Alexandria. He was a prolific writer who wrote roughly 2,000 treatises in multiple branches of theology, including textual criticism, biblical exegesis and biblical hermeneutics, homiletics, and spirituality. Origen is a Church Father. and is widely regarded as one of the most important Christian theologians of all time. Origen produced the Hexapla, the first critical edition of the Hebrew Bible, which contained the original Hebrew text as well as five different Greek translations of it, all written in columns, side-byside. He wrote hundreds of homilies covering almost the entire Bible, interpreting many passages as allegorical. The reading Bethabara on the west bank of Jordan River for the Baptism site became current owing to the advocacy of Origen, who did not recognized Bethany Beyond the Jordan during his time (John1:28). Now after recent excavations the site of Bethany Beyond the Jordan discovered on the eastern side of Jordan River, this discovery cast doubts on all theories guided by Origen and his followers during the early times of Christianity . ( see Waheeb 1997-2002).
} 
Edward Creswell (1834), however, writing in 1830, saw "no good reason for questioning the ancient ecclesiastical tradition, which supposes it to have been Mount Tabor." Creswell not sure from Mt Taboor and raised the possibility of other places for Transfiguration .

Dalman suggests three high mountains for Transfiguration south of Caesarea, upon the high plateau of the northern Jolan . (Dalman : 1924,219).

Hertzberg refers to a pagan cult upon Tabor (Hertzberg 1928: 174-176 see also Boehmer 1929: 161-169 ).

John Lightfoot proposed a third place for Transfiguration "some mountain near Caesarea-Philippi" The usual candidate in this case is Mount Panium, Paneas, or Banias a small hill situated at the source of the Jordan, near the foot of which, Caesarea Philippi was built. This site is not supported by scholars and researchers of archaeology, history and holy text ,so John Lightfoot rejects Tabor as too far . ( Lightfoot:1825)

A map printed and produced in London during 2008 showed another fourth place or site called Jabal Hermon ( s.no 88)on the western bank of Jordan River just north of Qumran caves and south of famous city Jericho. The location of this Hermon is situated somewhat opposite traditional spot of site of Jesus Baptism on the eastern bank of Jordan River/ Wadi Al-Kharrar .( www.Almaalem.com Sakhneen /). It seems that the littlie Hermon Mountain of eastern bank in Wadi Kharrar was shifted to the west bank for unknown purposes .

The Gospels record that Jesus was in the vicinity of Caesarea Philippi before the Transfiguration (Matt 16:13). Nothing suggests that he traveled especially to Mount Tabor. On the contrary some scholars refer to the eastern bank of Jordan River as a proposed site for Transfiguration, among of them Edward Creswell (1834) moved to the east to Jordan and raised the possibility of Mount Nebo as a Transfiguration place, where Moses possibly granted a view of the Promised Land . Nebo is an elevated ridge in Jordan, approximately 817 meters (2,680 ft) above sea level .( Creswell :1834).

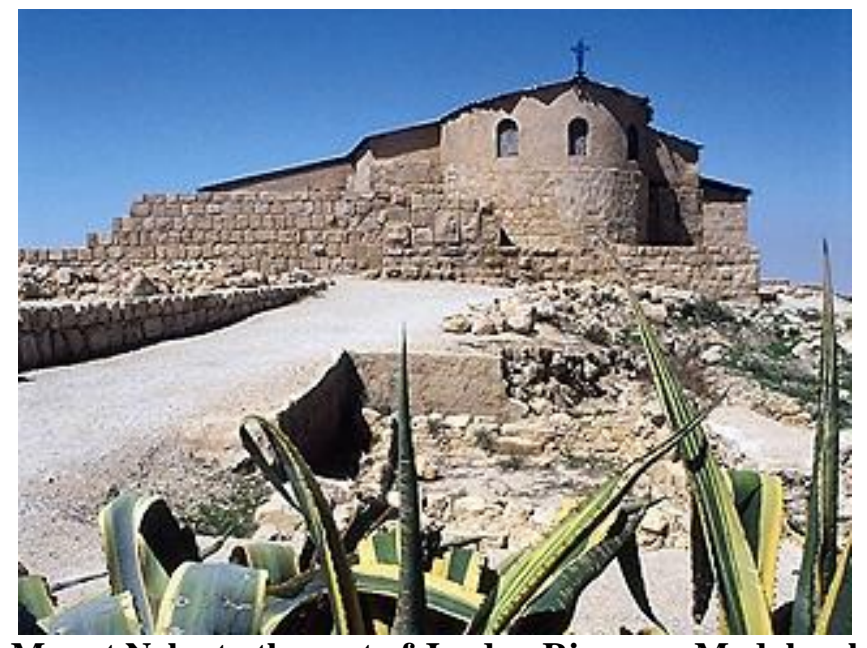

\section{B- Hermon}

Fig: 3 Mount Nebo to the east of Jordan River on Madaba slopes .

It is again objected that Our Lord was Transfigured on Mount Hermon, near Mt Tabor, since He was at that time in its vicinity. But the Synoptic are all explicit concerning the lapse of time, six days, or about eight days including those of departure and arrival, between the discourse in Caesarea and the Transfiguration, which would infer a somewhat lengthy journey. Moreover objected the summits of Hermon near Syrian borders that are covered with snow as late as June and even the lesser peaks of 4000 or 5000 feet are likewise snow-covered in February and March, the period of the Transfiguration.

Apart from it being very beautiful nobody knows much about the geographical features of Mt Hermon,. The name in the holy text occurs in plural (hermonim) but not Hermon which usually indicates people who live there, really this doesn't fits Hermon the snowy Mountain. The King James Version solves this conundrum by applying the word for land ("from the land of the Jordan") They tried to interpret the context, by saying, (it seems to call for a geographical location. also) while other scholars, translations and most commentators feel that this plural form reflects the multiple peaks of the Hermon complex, and insert words like "the peaks of" (NAS) or "the heights of" (NIV). BDB Theological Dictionary even proposes that the names Senir and Hermon are not different names of the same mountain but proper names of its different peaks, but there's no evidence for this either way. 
King James Version mistakenly renders this "the Hermonites" It must be a reference to the triple summits of the mountain. There are three distinct heads, rising near the middle of the mass, the two higher being toward the East. The eastern declivities are steep and bare; the western slopes are more gradual; and while the upper reaches are barren, the lower are well wooded, and as one descends he passes through fruitful vineyards and orchards, finally entering the rich fields below, in Wady etTein. The Aleppo pine, the oak, and the poplar are plentiful (see (Psalm 42:6).

According to the controversial research by Professor Knohl, in his book "Hashem", Mount Hermon is actually the Mount Sinai in Egypt (Knohl:2010)

R. T. France (1987) notes that Mount Hermon is closest to Caesarea Philippi, mentioned in the previous chapter of Matthew. Likewise Meyboom (1861) identified "Djebel-Ejeik." but this may be confusion with Jabal el Sheikh, the Arabic name for Mount Hermon

According to Steve Santini in his article entitled The Location of Mount Sion and the Real Hermon 2013, ( Until recently, there have been two locations identified as Hermon. One is a peak on the high mountain range in southern Lebanon, just north of the Sea of Galilee. The other is an area in a vale below the summit of Mount Tabor just six miles east of Nazareth). This second site was once known as Little Hermon both named Hermons and have been associated with the Mount of Transfiguration. However, based on previous misinformation regarding the location of Hermon these former locations for the actual Mount of Transfiguration are incorrect (Santini :2013)

Still, from the time of W. G. Mastermar's writing in 1939 until very recently, bible students and scholars have not had a definitive location for Hermon. (Santini :2013)

All this discussions reflects the hazy picture of the location among the scholars who involved in interpretation of the holy text compared with the traditional and recovered sites which lastly resulted in disagreement about the Hermon \&Tabor as the exact location of Transfiguration in the holy land. Turn back to the former question, where this event happened?

\section{C- The Discovery of Bethany Beyond Jordan( Baptism Site )}

The Baptism Site, $40 \mathrm{~km}$ west of Amman, is classified among mixed natural and cultural sites. Also known as Bethany Beyond the Jordan, the site is where Jesus Christ was baptized by John the Baptist, according to Christian beliefs. In 1996, the author initiated archeological survey and excavations, and historical research on the eastern side of the Jordan River where the Baptism site recovered, the work started from 1996-2002 followed by comprehensive field documentation and publications till nowadays (Waheeb1997-2001).

The newly discovered site Littlie Hermon, which called Elijahs Hill or ( Tel Mar Elyas in Arabic) on the eastern bank of Jordan River is among several important sites such as monasteries, churches, caves, and water system found during the systematic excavations in 1996 and followed by comprehensive documentation and gained world recognition in 2015 .

The question arise here, is this new Little Hermon/Elijah,s Hill is the real place for Transfiguration? If so what about evidences and proves to consider this site as a focal point and real site of this event.

This discovery turn us back to the question, where this glory happened and which mountain witnessed this sacred event?

To answer this problematic question we should go back to make deep assessment and evaluation of recent archaeological surveys and excavations conducted on the eastern bank of Jordan River during 1996-2017.

Still, from the time of Mastermar's writing in 1939 until very recent writings like Albright, Glucek , and other scholars have not had a definitive location for Hermon and the place of Transfiguration .

Elijah's hill ( Hermon) has strong potentials Up from a ford of the Jordan in this region, through a ravine, in which the Wadi Kharrar flows, where Elijah was taken up in a whirlwind( Wilkinson, 1981). The site once known as Elijah's hill (Kings:1)

From the fourth through eighteenth centuries, Christian pilgrims heavily traveled this area with knowledge of Hermon's presence here on the eastern bank of Jordan River.

In this new area of discovery where the "little hill of Hermon" stands, there is a range of steeply rising hills running along the eastern side of the Jordan River's course as well as sacred Wadies like Hesban,Seir,and Gharaba. (Waheeb 2012). 


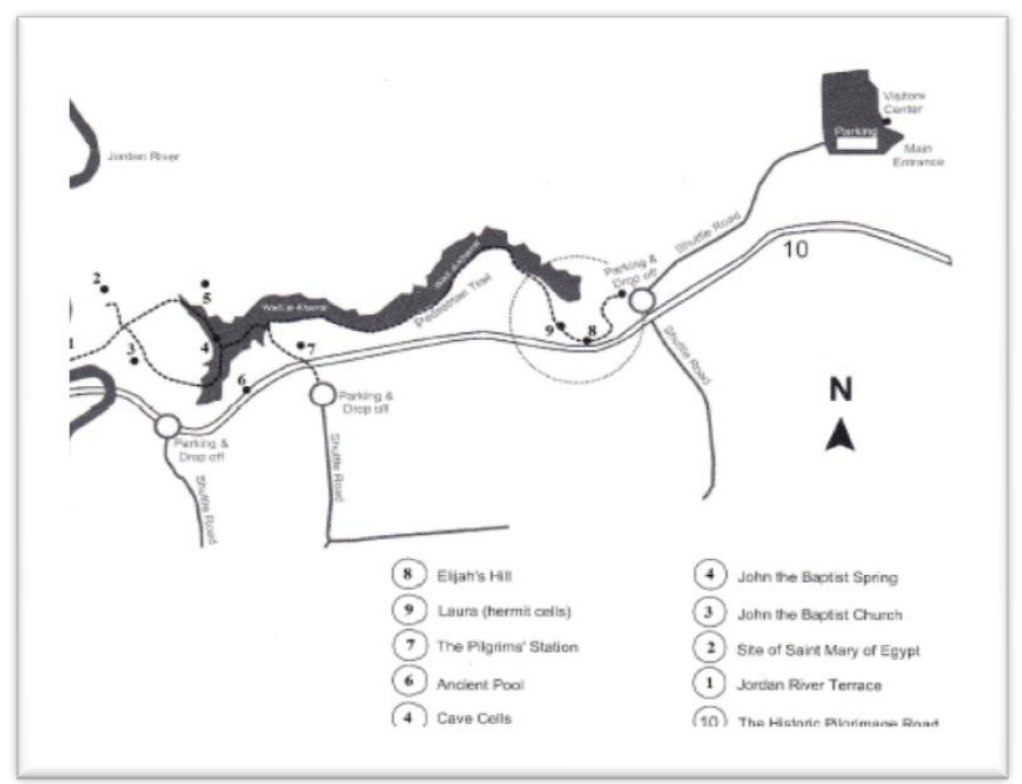

Fig 4 : General map showing the discovered sites in Bethany Beyond the Jordan s.no8 is Hermon (Waheeb: 2012)

This uplifted land elevates eastward to the Plains of Rama \& Kafrein in a span of 4 to $5 \mathrm{KM}$.

Since Hermon is written off as the same as Mount Taboor , this little hill of Hermon is functioned before (Tabor), and is one of the hills in the hill country of sacred sites associated with several events in Christianity, such as home of prophets and their existed holy shrines for Moses, Aroon, Joshua Elijah,Elisha,Gad,Job ,Hazeir, John the Baptist and Jesus as well as Baptism site ( John:1:28, 10:40), Aenon Near to Saleem( John 3:23) ,Pilgrims Road , Mount Nebo , and finally Little Hermon of Bethany Beyond the Jordan (LHBBJ)

\section{New Evidences \& the Discovery of (LHBBJ)}

When writing about these early Christian topographical identifications of biblically named sites, Mastermar wrote in the International Standard Bible Encyclopedia of 1939, "It was a period when Biblical topography was settled in a very arbitrary manner, without any scientific or critical examination of the evidence, and this tradition once established remained, like many such traditions, undisputed until very recent years" After the Roman Empire's destruction of Jerusalem in $70 \mathrm{AD}$ the name itself and its associations were "blotted" out for two Roman generations or 60 years. No writings or mentions of Jerusalem's name were allowed. The pile of rubble at the foot of the Mount of Olives remained nameless, as did the region about it until $130 \mathrm{AD}$ when the name of former Jerusalem was changed to Aelia Capitolina and the former Iudaea Province to Syria Palaestina. ${ }^{5}$

In the Roman reconstruction, during the period of Emperor Hadrian, many of the scriptural names and locations had been forgotten or hidden. It was not until then in this fourth century that focused attempts were made to re-identify the locations of events in Christian scriptural history. Over time with scientific methods and critical examinations of scripture, and of historical writings, corrections have been made to these earlier designations (Santini :2013).These corrections depended on new discoveries through field operations such as survey, excavations and the findings of inscriptions ,as well as readable old materials, such this case were applied to Bethany Beyond the Jordan Project .Survey and excavations were conducted in and around traditional place of baptism on the eastern bank of Jordan River to clarify several questions (Waheeb:1997).

Archaeological activities, started in 1899 with explorations in the area of the estuary of Wadi al-Kharrar of Bethany Beyond the Jordan, identified the remains of a church on the east bank of the Jordan. The first short account of the monticulus of Elias which mentions that it was about eighty-six yards long and forty-three yards broad was written by L. Federlin in 1902. On top he found many weather-beaten lumps of freestone which apparently had belonged to various buildings. He could not trace the plan of these, but one seemed to him to have stood about sixteen yards square (Federlin 1902, 154f).

\footnotetext{
5 . Note that we have another site called ( little Hermon ) was applied to the lowest slope of Tabor , this place not supported by any scholars .
} 
In 1931, D. Buzy made a more thorough examination of the hill and wadi. He too, used only his eyes, but vowed to begin excavations without delay. Unfortunately he never carried out his intention. He no longer found any hewn stones on the mount of Elias. When the sand is removed, however, "traces of the walls of houses appear everywhere". Ceramics and tesserae show that the hill was inhabited in Roman \& Byzantine times. Then he moved back along the course of the wadi, and thought he found traces there of fifty, or perhaps even a hundred houses (,Buzy 1931,458). A year later, Abel saw upon the hill "very clear traces of ancient foundations". He too, discovered weathered sandstone and a few pieces of ceramics down the wadi, but none earlier than Byzantine (Abel: 1932, 238f).

Wilken describes Palestine as it was under British mandate before the second world-war. He maintains that, on the slopes of the Mount of Elias there were pieces of pottery dating from the time of Christ, and near them, five rockgraves with contents belonging to the same period ${ }^{6}$.

This would have provided Bethany with an archaeological basis; but in the long time which elapsed between visiting the site and writing down the facts, many things became confused in his mind. The remains he describes were located in front of the remnants of a monastery. In addition, the remains of hermit's cells near the source of the wadi at Jabal Mar Elias/ Saint Elijah's hill were identified.

The two sites were visited until 1947 when, due to the political situation in the area, visits had to be suspended. The sixday war of 1967 resulted in this area of the river Jordan becoming a fortified zone and thus off limits to civilians. With the peace treaty between Jordan and Israel in 1994, the area was once again opened up for explorations.

Field excavations under direction of the author were started during the summer of 1996 as mentioned above, and revealed the presence of more valuable architectural remains, among of them the three monasteries Elijah,s Hill Monastery(Upper Area ), The Middle Monastery ( Middle Area ) and The River Monastery( The Lower Area) as follow:

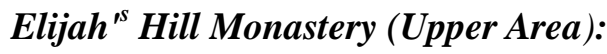

This Byzantine Monastery called Rhetorius monastery dated to (fifth- sixth centuries) located on St Elijah's hill (LHBBJ) at the western edge of Wadi al-Kharrar. It connects with the traditional place where Jesus was baptized, a distance of ca. $1.8 \mathrm{~km}$ to the west. It is on the pilgrimage route from Jerusalem to mount Nebo through Bethany beyond the Jordan. The name of the monastery comes from an inscription found in the apse of its northern church. The inscription reads: "By the help of the grace of Christ our lord. The whole monastery was constructed in the time of Rohetorius, the most God-beloved presbyter and abbot. May God the Savior give him mercy". (Waheeb1998:636).

The monastery is comprised of three churches and other buildings within an enclosure - a wall to protect from erosion rather than to serve a defensive function. An entrance in the northwestern wall leads to the living quarters of the monks.. . Greek orthodox monks established another monastery at the site, which consisted of structures for worship, residence, and accommodations for visiting pilgrims.In brief three churches, three pools, three caves and triple arched entrance were among the discoveries on this small low hill, other discoveries related to (LHBBJ) were :

A water system, consisting of a cistern and settling basins, is located near the Prayer Hall and the small chapel called the Church of John Paul II. It was dug out of the natural marl rock and is the largest reservoir discovered. A rectangular church or chapel, measuring $13.65 \times 9.45 \mathrm{~m}$, is located on the saddle of land south of Elijah's hill dated also to (fifthsixth centuries).( Waheeb:2000 ).More excavations to the southern area of LHBBJ revealed Early Roman remains dated back from the 1 st century $\mathrm{AD}$.

\footnotetext{
6 . Wilken II 118: "The potsherds on the slopes and at the foot of the hill belong to the time of Christ. Opposite the southern slope are to be found the entrances of two rock-graves, almost filled up with debris, and within the grave-chambers, as well as some bones, three skulls which immediately crumbled. In one of the chambers are two oil-lamps and three coins belonging to the reign of Herod Agrippa, we opened up three more rock-graves there. They contained nothing, it is true but their arrangement suggests that they belonged to the time of Christ.
} 

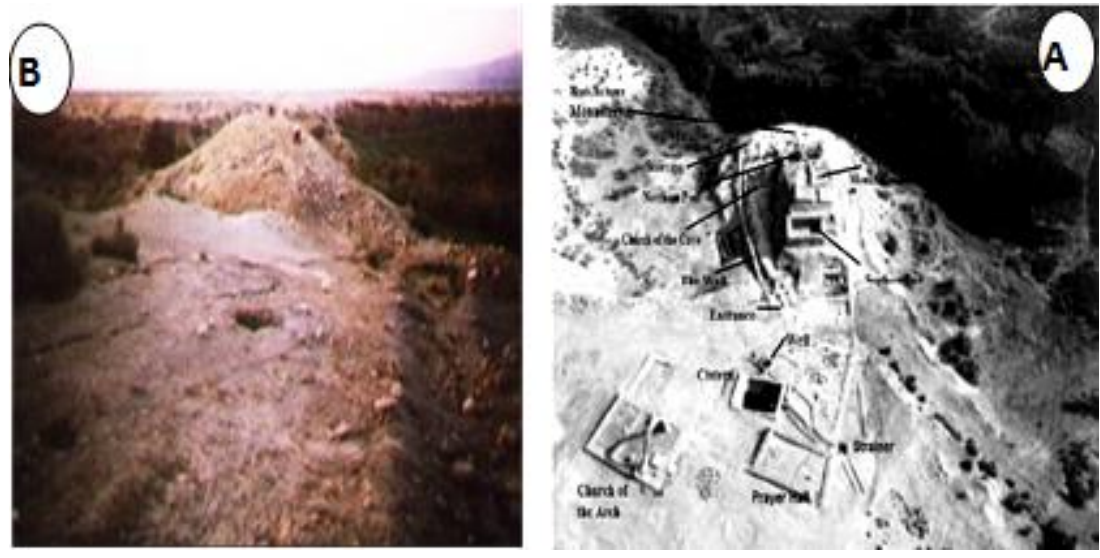

Fig 5 B: Elijah's Hill , Littlie Hermon before excavations during 1996 ( Waheeb 1996)

Fig 5 A: Elijah's Hill , Littlie Hermon after excavations ( Waheeb 2012)

\section{The Middle Monastery (Middle Area) the pilgrims'station:}

The monastery located between the Jordan River,or the River Monastery( The Lower Area) and the upper monastery ,Elijah ${ }^{\mathrm{s}}$ Hill /Tell al-Kharrar. It consisted of a number of rooms built for praying and daily life usage around an open courtyard, served by an adjacent water pool built during the fifth- sixth centuries AD.

The associated large pool in the lower area of the site, uncovered just east of the Jordan river, and was constructed of well cut ashlars and lime stones covered with plaster layer to prevent seepage .( Waheeb:1999 )

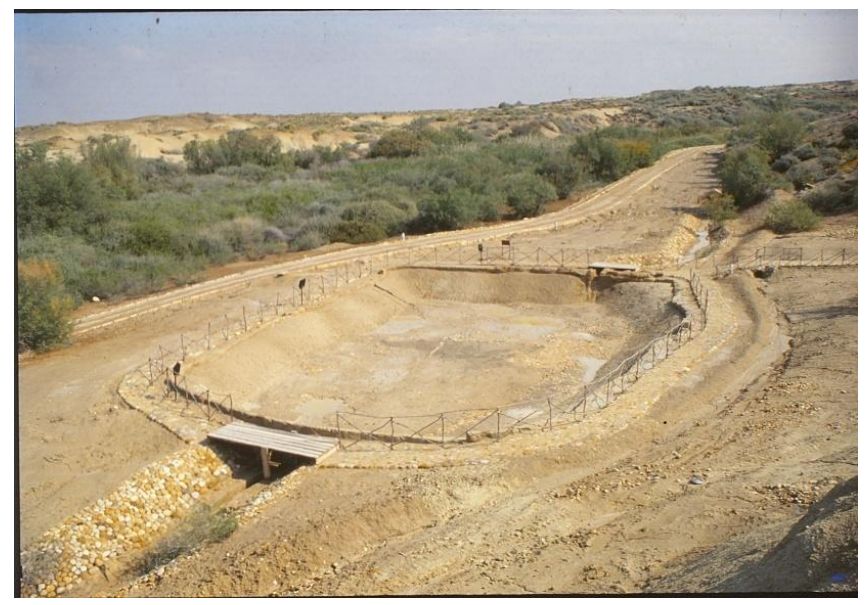

Fig 6: The large water pool of the Middle Monastery ( Middle Area )

\section{The Jordan River, the River Monastery (The Lower Area) John the Baptist church area:}

Remnants of structures within this area are: (the first church) a pillared hall; the lower basilica (the second church); and the upper basilica (the third church); a room discovered east of the basilica paved with different colored marble pieces leading down to a black marble staircase connected with a pier still standing nowadays ; a small chapel (the fourth church) also built there as known the lowest chapel on earth. All were built on the spot where believers located John's baptism of Jesus. Over the centuries, this series of churches was partly destroyed, by floods and/or earthquakes;

(Waheeb 2001: 600). Several caves were recovered close to the monastery; the caves were dug into the upper layers of the lissan marl cliffs and would have been used by monks as dwellings (cells). They have prayer niches carved into their eastern walls. (Waheeb 2000). Also the Site of Saint Mary of Egypt has been discovered here, which consisted of the remains of two adjacent structures dating from the early Byzantine period to Late Byzantine ${ }^{7}$ (Waheeb, 2004).

\footnotetext{
7 All these discoveries made the site more significant "The team worked hard in collaboration with high classified universities and institutions to excavate, analysis, and publish the recovered data and artifacts and managed to implement all requirements needed to add the Baptism Site on UNESCO list. The site had been recognized for its religious importance and now it is recognized as a world heritage site and added as UNESCO's World Heritage Sites in 2015, which adds more to its significance to attract more visitors.
} 


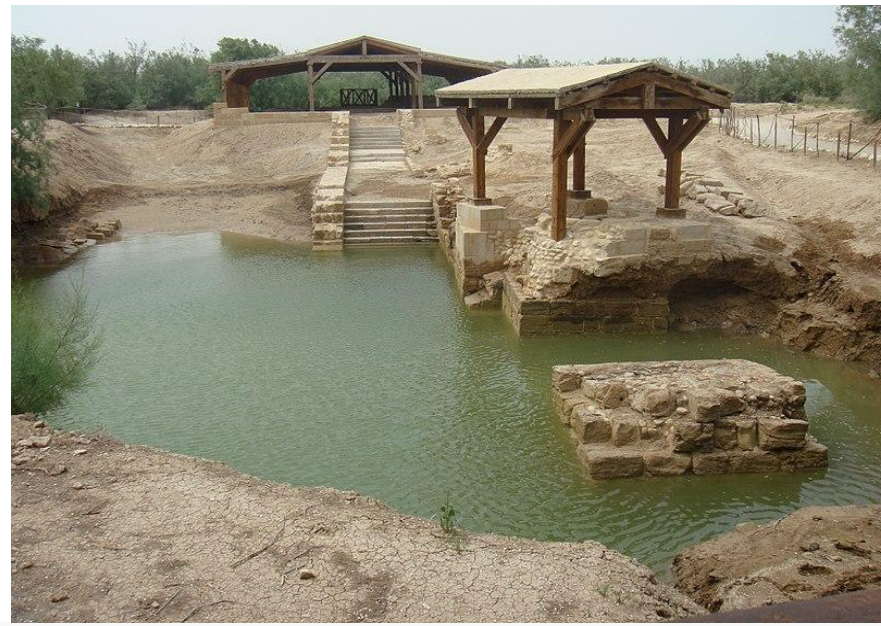

Fig 7: The River Monastery (The Lower Area) the eastern side of Jordan River, John the Baptist church area.

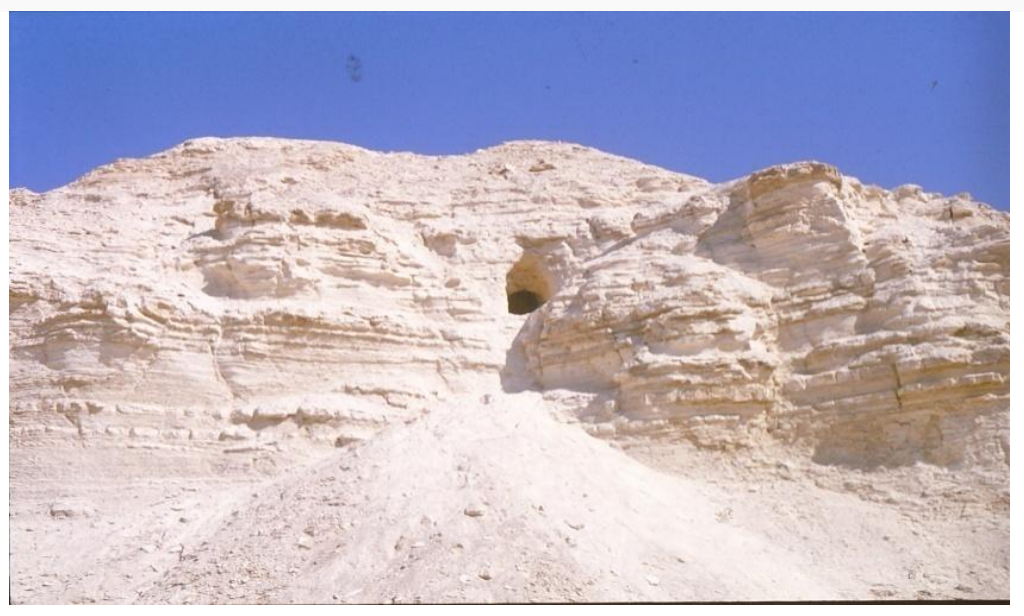

Fig 8: The Cave Cell on the eastern of Elijah's Hill (Waheeb:2002)

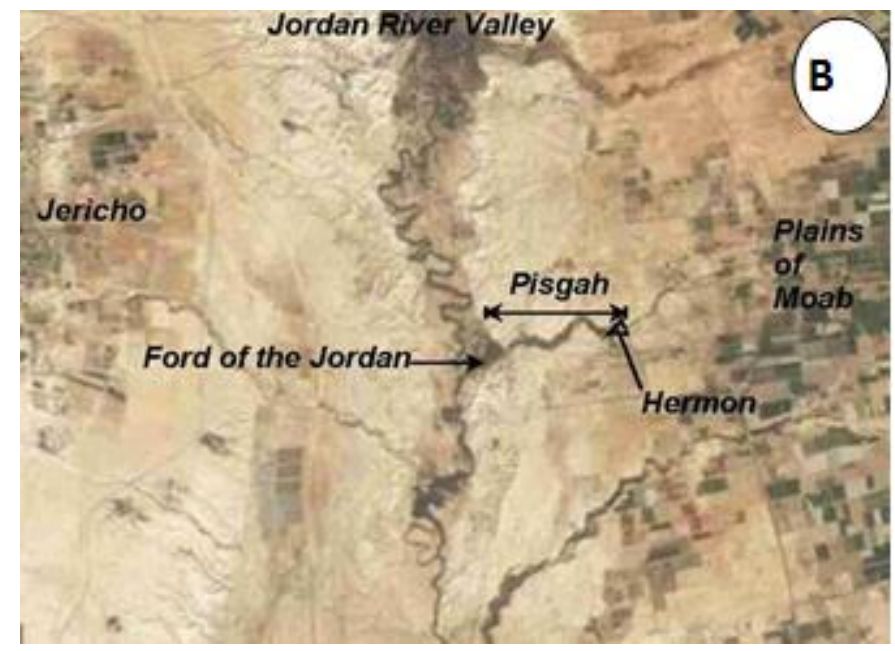

Fig 9 : Map refers to Hermon, Pisgeh, and Fords of Jordan

\section{The importance of (LHBBJ) during Roman Byzantine after excavation:}

Before the discovery of (LHBBJ) scholars have liked to look for the mount of Transfiguration in the vicinity of Caesarea on the west. .Now after systematic excavations on the east everything becomes clear enough to permit reconstruction of this historical gap which occurred on top of one of the lowest mountains on earth, but very high in spirituality. 
On descending the mount ,however ,Jesus found the disciples disputing with the scribes , and the healing of the possessed boy, which followed immediately, proves that he was in populated area, either town or village which fits Bethany beyond the Jordan and the surrounding area. Consequently the best place to seek the Mount of Transfiguration would be neither in the Jewish Diaspora around Caesarea , nor in a place too far away from towns and populated areas ,but in Perea on the eastern side of Jordan River, in Bethany Beyond The Jordan.

Several Classical villages or towns were found near (LHBBJ) to the east, south and north on the eastern side of Jordan River of a distance ranged approximately from $1-3 \mathrm{~km}$. The closest historical towns are Nimrin where a Byzantine church and considerable settlement were found to the northern east direction (Holmegren: 1997 ) While to the east 3 $\mathrm{km}$ Tell Kafrein, and Khirbet Kafrein a new Roman -Byzantine settlement were recovered among of them churches were discovered (Waheeb :2001), A unique monastery called Deir Al-Mullaga in Wadi Shueib (The Hanging Monastery) was found at a distance of $7 \mathrm{~km}$.

Numerous Mosaic pavements of cultic purposes were recovered during our field survey $2-3 \mathrm{~km}$ to the east, situated in close locations of (LHBBJ) among of them mosaics of Tell er -Rama, Mosaics of Rama Plain (Taziz Farm ) ,Mosaic of Maqam Al-Khader (St Georgious Shrine ) ,Mosaics of Sweimeh Cemetery, and the major site of Aenon Near to Saleem of John3:23 ( Waheeb : 2017). During her journey, Egerias refers to a several inhabited locations along the pilgrim's road from Jerusalem to Jordan River through (LHBBJ) and up to Mt Nebo (Wilkinson: 1981 ).

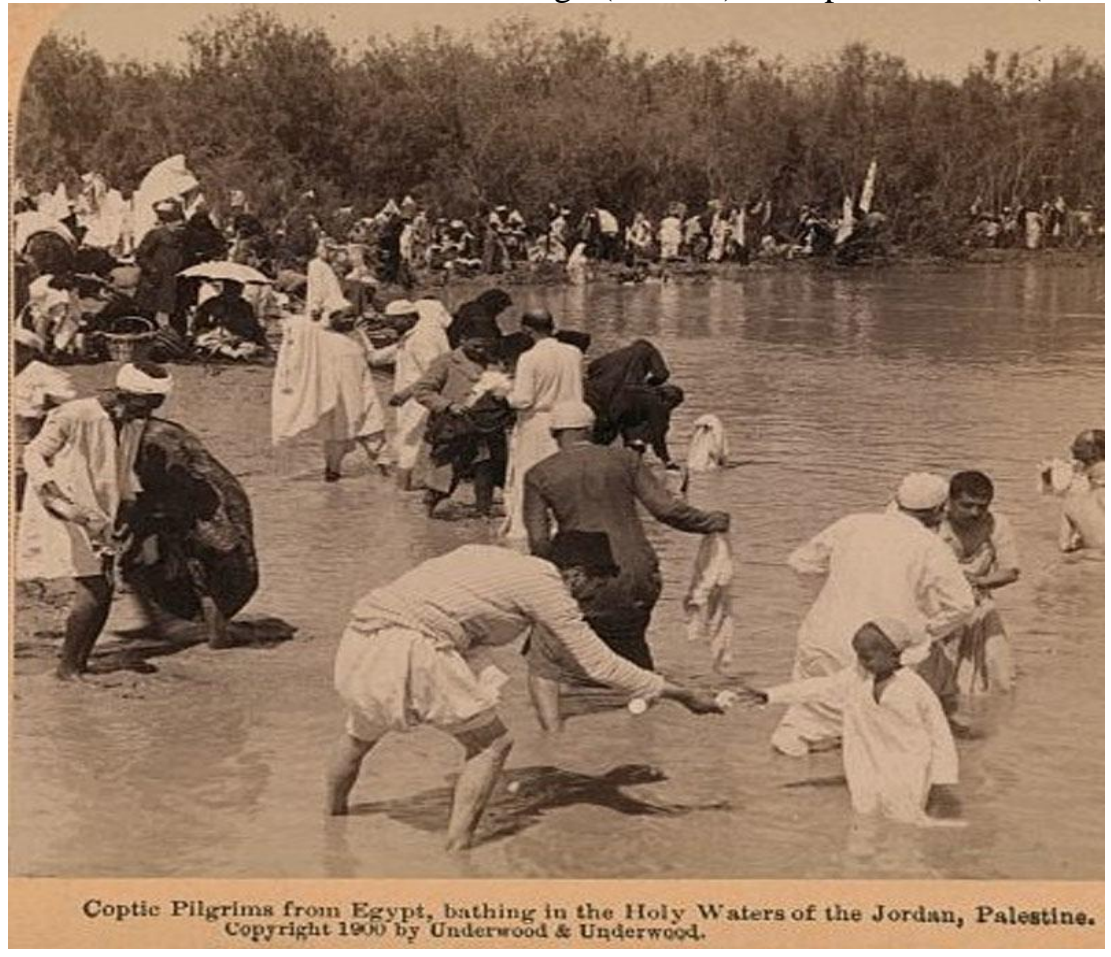

Fig 10: Christian Coptic from Egypt bathing in Jordan River in 1900

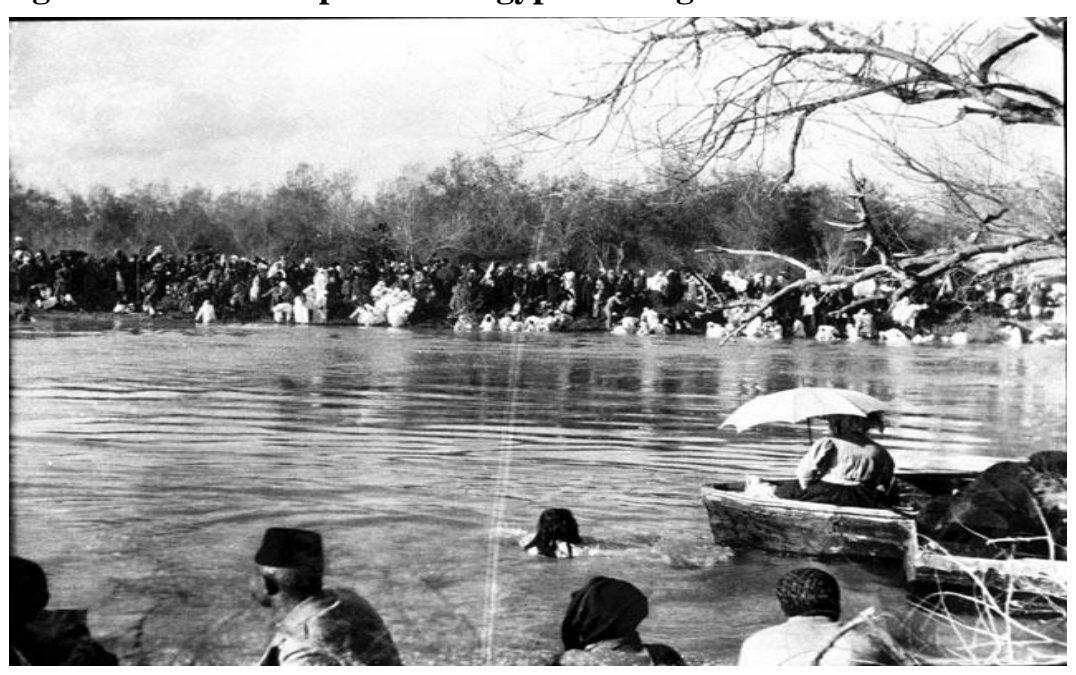


Fig 11 : The Baptism of the Russian pilgrims in the Jordan [Pilgrims in water. "The shrouded people clambered down the mud banks and stood waist deep in the stream until the moment when the priest laid the cross three times upon the water, then suddenly, with a great firing off of guns, every one proceeded to baptise himself by dipping and rolling over in the water. It was the strangest sight (Gertrudebell:1890).

\section{Historical and Travelers Description of ( LHBBJ ) :}

To the east beginning at the crest this range of relatively low hills is the 5 to $6 \mathrm{KM}$ wide plateau know as The Plains of Moab where Bethany Beyond the Jordan hosted early community of Jesus followers \& believers. Then at the eastern edge of the plateau Mount Nebo rises abruptly from the plain. While Jerusalem rises from the west mountains .the tow sites seems geographically hosted the little Hermon as the most high important site of spirituality in the lowest spot on the earth, Even before this recent discovery of Bethany Beyond the Jordan, both the other named Hermons have been associated with the Mount of Transfiguration. From the scripture the association of the two appears correct. However, based on previous misinformation regarding the location of Hermon these former locations for the actual Mount of Transfiguration are incorrect. Scriptural and historical information now point to Elijah's Hill (Tell Mar Elyas) near Mount Nebo as the location for the Mount of Transfiguration.

What support little Hermon on the eastern bank of Jordan River to be the real location of the glory event is the description of pilgrims and travelers who visited the area and reached the sacred site such as Hermon, among of those pilgrims and travelers St Hellana , Theodosius ,Pilgrim of Bourduxe,Antonius ,Arculf, Willbllad .......etc .

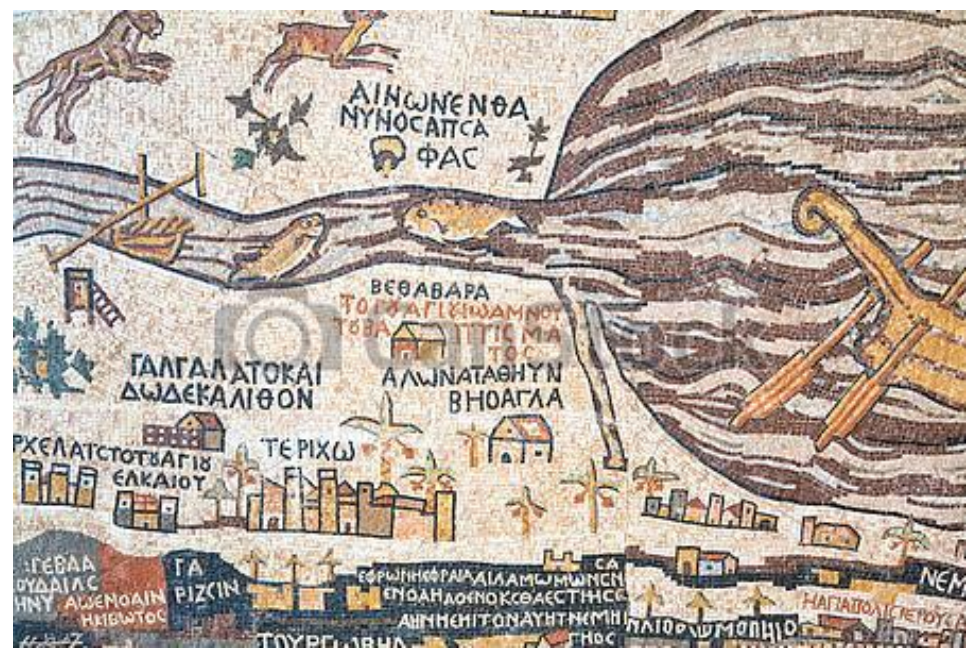

Fig 12: Madaba Mosaic Map showing the River Jordan \& Bethany east of the River

It was in this area on the other side of the Jordan that both Moses and Elijah disappeared. Reasonably, the most significant location for their confirming reappearance with Jesus Christ would be in the locale of their original transformation into the purely spiritual realm. Some said by appearing with him Moses and Elijah confirmed that he is the fulfillment of the Old Testament. Here also John \& Jesus established the first disciples circle and by Transfiguration he prepared them a second time for his violent death so the disciples or the three of the church were to understand Good Friday ${ }^{8}$.

In $1173 \mathrm{AD}$ the German monk, Theoderich, wrote that on one night there were 60,000 pilgrims with candles in this area around the Jordan. In 1848 Lieutenant William Lynch led a small expeditionary contingent of US seamen on a scientific expedition down the Jordan River to the Dead Sea. Under a full moon on one spring night, while encamped on the east bank of the Jordan near the ford, Lieutenant Lynch was awakened by a shout to experience the following:

"The pilgrims are coming, get out of the way!"...the ground was shaking....we beheld thousands of torch lights with a dark mass beneath, moving rapidly over the hills.......in one tumultuous and eager throng. In all the wild haste of a disorderly rout, Copts, and Russians, Poles, Armenians, Greeks, and Syrians, from all parts of Asia, from Europe, from Africa, and from far-distant America, on they came, men women and children, of every age and hue, and every variety of costume; talking, screaming, shouting, in almost every known language under the sun.

\footnotetext{
8 . Luke 9:31 mention that Jesus spoke with them about his death in Jerusalem .After the first coming of Jesus Christ countless numbers of pilgrims have traveled a pilgrimage route from Jerusalem on the west, to the Jordan's ford crossing toward Elijahs Hill \& Bethany Beyond the Jordan( John1:28) Wadi Al- Kharrar and many times onward to Mt Nebo in the mountains of Madaba directly to the east.
} 
Along this pilgrims route there were several pilgrim stations constructed along the old Roman Road (Esbus-Jericho ) among of these stations are Wadi Gharaba Station ( Waheeb:2017 ) Livias station/ Tell er-Rama, Aenon near to Saleem (Waheeb :2017) \& Al-Mahata , that provided rest and services for the pilgrims on their journeys. Those pilgrims knew that there was a connection between Jerusalem and Bethany Beyond the Jordan . They also has a knowledge about Elijahs Hill, the place of ultimate salvation written of in the Gospels, lay below Mt Nebo on the western edge of the Plains of Livias down through which a ravine cuts to the ford across the Jordan. This gently sloping ravine now named Wadi Al-Kharrar is the Pisgah written of in association with Hermon and Sion in Deuteronomy chapter four.

Pilgrims made their way down the ravine that was cut through the hills to the ford of the Jordan at the ravine's foot where Jesus was baptized. They traveled this way as did the prophets before like Moses \& Elijah . It is most certainly the way John the Baptist, Jesus Christ and his apostles traveled.

In $129 \mathrm{AD}$ the Roman Emperor Hadrian constructed a Roman road from Heshbon on the ancient north-south Kings Highway to connect Jericho across the Jordan. This road was called ( Esbus -Jericho ) built upon the ancient incense route over the northern flank of Mt Nebo, across the Plains of Livias, down littile Hermon, across the Jordan ford where Jesus had once been baptized, onward to Jericho and then up to Jerusalem. The meaning of Hermon is appropriate for this wadi as it is surrounded by holy sites from all directions through the plains of Livias as it descends to the Jordan. Hermon in Arabic means the hlly zone of sacred either shrine or church, cemetery or holy routes. Jesus, the Christ, did come out of Bethany. First he came out of Bethany to be baptized by John the Baptist as the Savior for his kinsmen ( John 1:28).

Then he came out of Bethany when the Jewish hostile dismissed him and escaped ( John 10:40), and last time came for Transfiguration on Elijahs Hill with Elijah and Moses. This time though he came out of Bethany as the Christ the Son of God for the salvation of the whole world.

So Jesus, the Christ, did come out of Bethany Beyond the Jordan three times and he will again come out of Bethany. The next time it will be with his fulfilled one body comprised of the saints and the resurrected first fruits of faithful in Christ Jesus, together, for the eventual salvation of all other men.

There is an indication from the holy text verse that confirms this location beyond the Jordan as Hermon. The Pilgrim from Piacenza also wrote around $570 \mathrm{AD}$ this of the area:

"This is the place where Elijah was taken up (to heaven). In that place is the 'little hill' of Hermon mentioned in the Psalm. "he continued "At the foot of the mountain at seven o'clock in the morning, a cloud forms over the river, arriving over Jerusalem at sunrise, above the basilica on Zion, the basilica at Christ's Tomb and basilica of Saint Mary and Saint Sophia (once the Praetorium where Christ's case was heard). Above these places the dew comes down like showers, and sick people collect it. In the hospices all the dishes are cooked in it, and in the places where this dew falls many diseases are cured. For this is the dew of which the Psalmist signs, 'it is as if the dew of Hermon were falling on Mount Zion ") ( Wilkinson, 1977). Psalm 133 states:

Behold, how good and how pleasant it is for brethren to dwell together in unity!

It is like the precious ointment upon the head that ran down upon the beard even Aaron's beard: that went down to the skirts of his garments;

As the dew of Hermon, and as the dew that descended upon the mountains of Zion: for there the Lord commanded the blessing, even life for evermore.

The dew from the distant mountains of Lebanon to the north or from Mount Tabor does not fall on Jerusalem in the mountains of Zion. The rising moisture from the Jordan and Dead Sea to the east of Jerusalem is caught by the prevailing morning breezes and does fall on Jerusalem as dew, especially in late summer and early fall.

So here across the Jordan about 30 miles directly east of Jerusalem lies Bethany - the land to which the wedding guest will be taken by the holy angels for the fulfillment of the revelation of the great mystery given to the apostle Paul by the ascended Lord Jesus Christ. 


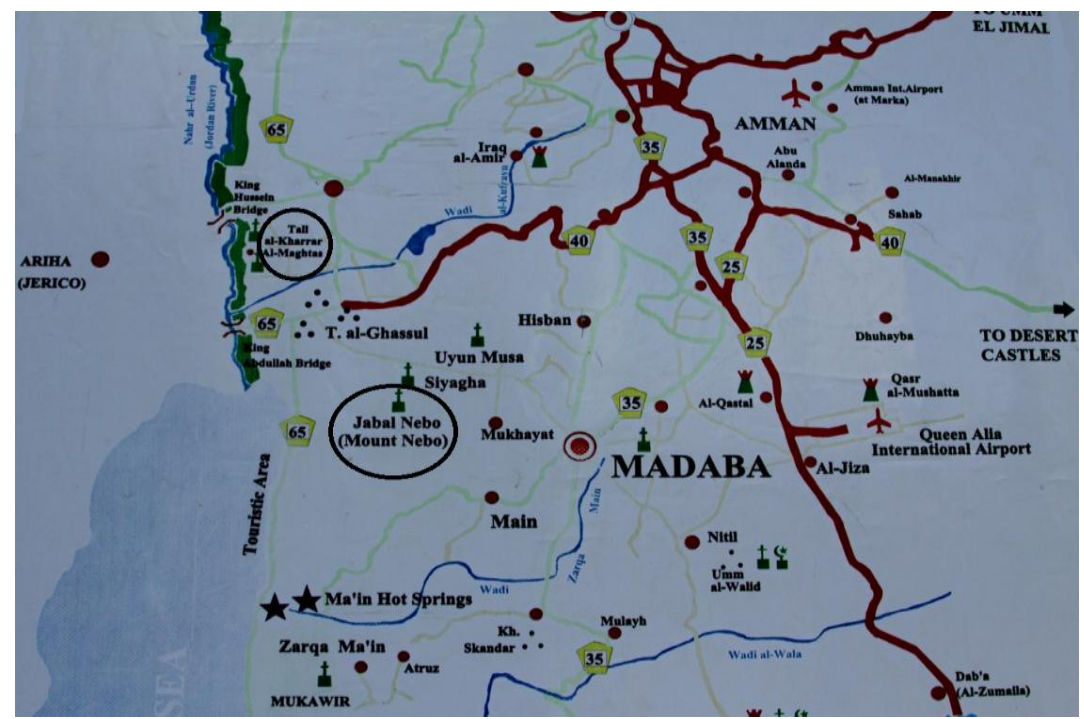

Fig 13: showing Hermon Hill and Mount Nebo east of Jordan River

Similarly, In $530 \mathrm{AD}$, the Western pilgrim Theodosius wrote of his pilgrimage beyond the Jordan . He wrote, "Where my Lord was baptized there is, on the far side of the Jordan, the 'little hill' called Hermon, where Saint Elijah was taken up".( PPTS : 1893)

This location appears to be in harmony with the descriptions in the gospel of Luke. If it is, as it appears, then all major events for John and Jesus is also in this area. First, the word high mountain used with Greek language basically means an uplifted area of land. The Greek word is translated in the English bible as mountain, mount, hill and hill country depending on the gospel context and the topographical understandings of the purposed regions when the original texts were translated.

\section{Discussion \& Conclusions:}

There appears to be little doubt that the Wadi al-Kharrar can be associated with the Prophet Elijah's ascension to heaven. It was at the eastern end of the wadi that believers placed his departure from earth by means of "a chariot and horses of fire" as he "ascended in a whirlwind into heaven." The location fits well with the biblical narratives relating the crossing of the nearby Jordan by Joshua and the parting of the waters by both Elijah and his successor Elisha. This could also be the location of Wadi Cherith, to which Elijah fled form Ahab, and where he was fed by ravens in the morning and the evening. John the Baptist and his connection to Elijah fit equally well in the region of Wadi al-Kharrar. Believers saw the promise of Elijah's return fulfilled in the coming of John. It was here, at "Bethany beyond the Jordan," that John lived during the time of his ministry. Disciples, who were associated with his baptizing and preaching activities, would have been his companions.

It was to "Bethany beyond the Jordan" that Jesus came to be baptized by John.

The place was convenient as it was the place of Transfiguration, which becomes one of the places where travelers would have crossed the Jordan on their way east or west. After receiving the message of departure from God on Mount of (LHBBJ) Jesus turned north again to Capharnaum and went down to the lake to take a last farewell ,before setting off for Jerusalem the same road .This chronological sequence fits the tangible evidences of archaeological heritage on the eastern bank of Jordan River .

Believers, as archeological investigations have shown, commemorated the place of Jesus' baptism by a series of churches and a monastery that, according to the "Piacenza pilgrim", contained two guest houses. Moreover, following John's death, Jesus retired to this area when the religious authorities in Jerusalem began to put pressure on him.

In Conclusion, the biblical texts, early pilgrims' reports, the Madaba mosaic map, as well as recent archeological work all agree in locating the place of the activities of John the Baptist and the baptism of Jesus and Transfiguration event east of the Jordan River at Bethany beyond the Jordan, on Elijah's Hill.

Moses and Elijah both appeared on little Hermon Hill, and both represent the two principal components of the Old Testament: the Law and the Prophets. There is no need to get into all the details of the Elijah prophecy again here. Review what was said in the holy text Study of Matthew 11. Here Jesus' words state that John came in fulfillment of the Elijah prophecy, what happened here on Hermon on the eastern bank of Jordan River is that Elijah was taken up to glory in the whirlwind and the chariot of fire. Here also on this little Hermon the two of them Moses and Elijah 
(Both ended and left on the eastern bank of Jordan River ) speak to Christ, and the parallel accounts tell us they spoke of Jesus" "departure". (They spoke of His coming death).

Accordingly Moses was the giver of the Law, and Elijah was considered the greatest of the prophets while the little Hill honored by the meeting of the three prophets. while the three disciples are witnesses on this glorious event, and later the Byzantine built here on the mountain three arches as a significant entrance with three churches, and three pools , all possibly represent the commeration magnificent Transfiguration and the holy trinity, where the heavens opened three times, one for Elijah's when he ascended by the horses and fiery chariot, secondly for Jesus tow times first when he baptized and second when he transfigured and in both he heard the blessing voice. It is more than probable that summit of this little Hermon was the scene of the Transfiguration, as it stands near Nebo, opposite Jerusalem, where we know Christ was just before that event several times.

There are more than two places of worship of john the baptist and Jesus Christ found on the eastern side of Jordan river ,first the baptism site (Bethany beyond the Jordan) (John 1:28) in Wadi Al- Kharrar, second Aenon Near to Saleem (John 3:23) in the lower area of Wadi Hesban, and a new discovery in Tyrue in Iraq Al Ameer in Wadi Seir down to Wadi Kafrein ( John1:35,Barnabas99:1).

Finally Mt. Little Hermon is the source of many blessings to the land over which it so proudly lifts its splendid form. Refreshing breezes blow from Jordan River. Winds of the river coming through the Jungle of Jordan are carried to Hermon and to the nearby towns on the borders of Livias, mitigate the heat of the Bethany summer. Holy pools and wells in the depths of the little mountain, fed by the springs water, find outlet in the magnificent Wadi Al-Kharrar mixed with other wadi springs fed the river Jordan at the spot where John and Jesus met and Baptized, while the heavens is opened a voice coming down here met crying voice in the wilderness. The event was intentionally private and connected with John the Baptist, and a setting on Mount Hermon would be more suitable than a location on other mountains in the holy land .

\section{References}

Abel R. (1932). Exploration du sud-est de la Vallee du Jordain, RB, 43 (Suie et fin), 237-263.

Abel R. 1938, Histoire de la palastina, Paris, see also Geograhie de la Palastina,2 vole, Paris .

Abu-Shemis, A and Waheeb, M. 2002 Pottery of the Baptism Site, Annual of the Department of Antiquities of Jordan, 45.

Alford, Henry". 1808 Encyclopedia Britannica (11th ed.). Cambridge .

Allita,E. andPiccirillo, M., 1999. MadabaMapCentenary.

Allita, E., \& Piccirillo, M. (1999). Madaba Map Centenary 1897-1997. Jerusalem.

Alt K Kleine 1953, schriften zurgeschichte des vol kesisrael, Munich.

Anonymous, 1894, Anonymous Pilgrims $1-$ Vill, $11^{\text {th }}-12^{\text {th }}$ Centuries, PPTS.

Antoninus Martyr, 1896, Holy Places Visited by Antoninus Martyr, 560-570 A.D. PPTS, Translated by Aubrey Stewart, pp. 1-37, 24, Hanover Square, London.

Arculfs, 1895, The Pilgrimage of Arculfus in the Holy Land 670 AD, in PPTS, vol. 3, Translated and Annotated by James Macpherson, pp. 1- 64, 24, Hanover Square, London, AMS Press, New York.

Avi-Yonah, 1954, Madaba Mosaic Map, Jerusalem.

Bernard, D.D.1893 "Theodosius on the Topography, Biblcum Franciscanum, Jerusalem.

Boehmer, B 1929,Zeit-Schrift F semitistik, 7,161-9

Brownow, C.1895. "The Hodceporicou of Saint Willibalad (Circa 754 A.D), PPTS: P.1-36.

Buzy, R 1933, Bethanie au dela du Jourdain: Recherches

Byzantine Period, Yale University, U.S.A.

Conder, R. (1982), Survey of Eastern Palestine, London.

Creswell, Edward (1830). Dissertations upon the principles and arrangement of a harmony of the Gospels

Dalman, 1924, Orte, u.wege Jesu,Gutersloh.

Damhoureyeh, S and Khader, I 2003 Vegetation Ecology

Dänial, Abbot. 1895. The Pilgrimage of the Russian Abbot

Danial in the Holy Land, 1106-1107, in PPTS, vol. 4, Annotated by Sir. C. Wilson, pp. 1-82, Hanover Square, London. Darf Publishes Limited, London.

Holmgren\& Kaliff,A, Excavations of Dayer AlQattar Al-Byzanti,1997, ADAJ, 41,321-340

Diary of A. Pilgrimage, Newman Press, Newyork.

Disi, A., Katbeh, A., Damhoreya, S., Wardarn, B., Amr, Z., Khoury, F., Khader, I. And Budieri, A., 2001, Jesus Christ Baptism Site Management Plan, unpublished report, Amman. 
Donner, H 1965. The Mosaic Map of Madaba, An

Donner, H.1971. "Account of the Holy City and the Holy Places", ZDPV, Vol.87, P: 66-87.

Eusibus,W,1904 Das Onomasticon der biblischenortsnamen ,leipzg .

Federal, L. (1902-1904). Recherché Sur Les Laures et Monasteries de Ia Plaine de Jordain, du desert de Jerusalem, Ia Terre Sante, 19(1902), 129-132.

Field, H.M.1888. "On the Desert: A Narrative of Travel from Egypt through the Wilderness of Sinai to Palestine,

T.Velson and Sons, Paternoster Row, Edinburgh; and Newyork.

Finigan, B. 1969. Archaeology of the New Testament,USA.

Flanagan, W. J., McCreery M. and Yassine K. 1996. Tell Nimrine: Preliminary Report on the 1995 Excavations and Geological Survey. ADAJ, 40: 271-293.

France, R (1987). The Gospels According to Matthew .An Introduction and Commentary Inter-Varsity.

Gertrude, B 1890, Gertrude Bell Collection, Newcastle University .

Gingras, G.1970. "Ancient Christian writers: Egeria: Great Britain.

Harding, L.UD. "Bassat el-Kharrar, Unpublished Report,,DAJ Archive .

Hertzberg,j 1928 Journal of Palestine Oriental Society ,8,174-6

Hirschfield, Y. (1992), The Judean Desert Monasteries in the

Hoade, E.1954. "Western Pilgrims, Publications of the Stadium

Hodge, A. 1992. Roman Aqueducts and Water Supply

Holmagren, R 1997, The 1995 - 1996 Excavation of International Standard Bible Encyclopedia -Hermon -". 1915

Introductory Guide Netherland.

Knohl, I,2010, Pharaoh's War with the Israelites: The Untold Story Azure Magazine \#41, Summer 2010 (Azure Magazine website)

Kopp, C 1963, The Holy Places Of the Gospels, Germany

Lightfoot, J Palestine exmonumenties veterhbus illustrrrata

Lightfoot, John (1825). The Whole Works of the Rev. John Lightfoot: Master of Catharine Hall, Cambridge. Vol 1. London: J.F. Dove.

Meistermann, Barnabas (1912), "Transfiguration", The Catholic Encyclopedia, XV, New York: Robert Appleton Company

Merrill, S.1986. East of the Jordan: A Record of Travels and Observation in the Countries of Moab, Gilead, and Bashan, 2nd.Edition

Morton, H.1934. "In the Steps of the Master, London".

Moschos, John. (1992). The Spiritual Meadow, Translated by John Wortley. Christian Publications, USA. New Jersey.

No 30(2) PP230 - 240.

Piccirillo, M. (1987). The Jerusalem-Esbus Road and its sanctuaries in Trans-Jordan, 165-172. Studies in the History and Archaeology of Jordan 31(1st ed.). A. Hadidi. Amman: Department of Antiquities, 11-1919.

Piccirillo, M. (1996). La Strada Romana Esbus-Livias, Liber Annus, 46, 285-300.

PPTS, 1889 The pilgrimage of the Holy Paula by St. Jermo 382 A.D, 1897-1997, Jerusalem. Registration Center of Department of Antiquities of Jordan, Amman.

Santini ,s 2013 The Location of Mount Sion and the Real HermonThe Place of Salvation? From the Series, the Anchor of the Soul

Taylor, J. Christians and the Holy Places. The Myth of Jewish-Christian Origins, Oxford: Clarendon.

The Holy Land", PPTS: P. 1-19.

Waheeb, M 2012 .The Discovery of Elijah's Hill and John's Site of the Baptism, East of the Jordan River from the Description of Pilgrims and Travelers ,Asian Social Science Vol. 8, No. 8; July

Waheeb, M. (1997). Report on the Excavations at Wadi al-Kafrein Southern Ghor (Al Aghwar). ADAJ, 41, 463-468.

Waheeb, M. (1998). New discoveries near the baptism site, Occident and Orient, 3(1), 19-20.

Waheeb, M. (1998). Wadi al-Kharrar al-Maghtas, AJA, 102(3), 601.

Waheeb, M. (1998). Wadi al-Kharrar Archaeological Project, ADAJ, 43, 635-638.

Waheeb, M. (1998). Wadi al-Kharrar, AJA, 102(3), 106.

Waheeb, M. (1999). Wadi al-Kharrar Archaeological Project. The Monastery, ADAJ, XLIII, 549-557.

Waheeb, M. (2001). Archaeological Excavations at the Baptism site Bethany Beyond the Jordan. Bible and Spade, 14(2), 43-53.

Waheeb, M. (2001). Wadi al-Kharrar Archaeological Project. The Survey Studies in the History and Archaeology of Jordan, VII, 591-601. 
Waheeb, M. (2002). Cultural Resources Management of Bethany Beyond the Jordan, Seventh International Forum UNESCO - University and Heritage Conference 6-20 December, Yarmouk University in Collaboration with Hashemite University, Jordan .

Waheeb, M. (2002). Wadi al-Kharrar. AJA, 106, 445-449.

Waheeb, M. (2004). The Discovery of Site of St. Mary of Egypt. Amman, al- khat al- arabi press .

Waheeb 2017 The Discovery of Tall Mar Elyas, in The Baptism Site, Jordan, 2nd edition, Amman.

Wilken, R. (1953).Biblisches Erleben im Heligen land 2 vol

Wilken, R. (1992). The Land Called Holy: Palestine in Christian History and Thought. New Haven, CT: Yale University

Wilkinson, J. (1976). Christian Pilgrims in Jerusalem during the Byzantine Period. Palestine Exploration Quarterly, $108,75-101$.

Wilkinson, J. (1977). Jerusalem Pilgrims Before the Crusaders. Aris and Philips Publishers, England.

Wilkinson, J. (1981). Egerias Travels to the Holy Land. Jerusalem.

Wilkinson, J. (2002). Jerusalem Pilgrims before the Crusaders (2nd ed.). Aris and Philips Publishers, England.

Wilson. C.W. (et). (1895). The Pilgrimage of the Russian Abbot Daniel in the Holy Land. 1106-1107 AD. Palestine Pilgrims' Text Society 4. London. Palestine Exploration Fund. 